\title{
Are Populists Sore Losers? Explaining Populist Citizens' Preferences for and Reactions to Referendums
}

\author{
Hannah Werner ${ }^{1 *}$ (D) and Kristof Jacobs ${ }^{2}$ (D) \\ ${ }^{1}$ Centre for Political Science Research, KU Leuven, Leuven, Belgium and ${ }^{2}$ Department of Political Science, IMr, Radboud \\ University, NL \\ ${ }^{\star}$ Corresponding author. Email: hannah.werner@kuleuven.be
}

(Received 3 September 2020; revised 6 April 2021; accepted 2 June 2021; first published online 23 September 2021)

\begin{abstract}
Can referendums help increase perceived legitimacy among citizens with populist attitudes? Indeed, public opinion surveys show that populist citizens are especially in favour of referendums. However, we do not know whether this support reflects a principled desire for different decision-making procedures or an instrumental one (that is, because they expect referendums to yield favourable outcomes). We study this question on a real-life case: the Dutch 2018 referendum on the Intelligence and Security Services Act 2017. Using high-quality survey data from both before and after the referendum, we find that, counter to conventional wisdom and our hypotheses, populists' support for referendums is less driven by instrumental motives compared to that of non-populists, and that populists are more likely than non-populists to accept the outcome of a referendum, even when this outcome is unfavourable.
\end{abstract}

Keywords: democratic innovations; referendum; populist attitudes; political behaviour

Populism is on the rise and the feeling that politicians do not listen to citizens is widely shared (see Rooduijn 2019). As a response to these widespread feelings, politicians often resort to organizing referendums (Bowler and Donovan 2013; Bowler, Donovan, and Karp 2007; Marien and Kern 2018; Scarrow 2001). However, little is known about the impact of these referendums on the citizens whose desires it wishes to meet, especially those with higher degrees of populist attitudes. ${ }^{1}$ A limited number of studies has examined the relationship between citizens with a higher degree of populist attitudes and preference for decision-making via referendums. These studies suggest that citizens with a higher degree of populist attitudes (for ease of formulation, henceforth, 'populist citizens') ${ }^{2}$ are especially supportive of decision-making via referendums (Bjånesøy and Ivarsflaten 2016; Jacobs, Akkerman, and Zaslove 2018; Mohrenberg, Huber, and Freyburg 2019).

But does this mean that they consider the outcomes of these referendums as more legitimate? So far, no study has examined this empirically. This matters because it seems that when populist parties lose a referendum, they do not 'take "no" for an answer' (Verdugo 2017; see also Pállinger

\footnotetext{
${ }^{1}$ Citizens can be dissatisfied with democracy for many reasons. On top of that, they can have different views of the competence and nature of 'the people'. Depending on those views, they are likely to favor different remedies such as expert, deliberative or direct democracy. For citizens with higher degrees of populist attitudes, referendums are the most likely remedy, hence our focus.

${ }^{2}$ For ease of formulation, we refer to populist attitudes in a binary way. However, empirically, we conceptualize and measure populist attitudes in a continuous dimension, ranging from low populist attitudes to high populist attitudes (see the method section).

( ) The Author(s), 2021. Published by Cambridge University Press. This is an Open Access article, distributed under the terms of the Creative Commons Attribution licence (http://creativecommons.org/licenses/by/4.0/), which permits unrestricted re-use, distribution, and reproduction in any medium, provided the original work is properly cited.
} 
2018; Silva 2020). Furthermore, recent research on process preferences has found that, in general, citizens' support for referendums is often driven by instrumental considerations (Landwehr and Harms 2019; Werner 2019). Is it possible that the demand for referendums among citizens with populist attitudes is primarily an expression of the hope that referendums can function as a shortcut to materialize their own policy preferences? If they do indeed also not "take "no" for an answer', holding referendums could backfire and undermine the legitimacy of the political system even further.

Using the case of a real-life referendum, we study whether populist citizens' attitudes and reactions towards decision-making through referendums are more or less driven by instrumental concerns than those of their non-populist counterparts. We find that, counter to our expectations, populist citizens turn out to be less instrumental and more principled in both their preference for and reactions to a referendum.

\section{Populist Attitudes and Referendums}

We understand populism as a set of ideas that: (1) are people-centred; (2) understand society as a conflict between the people and the elite; and (2) take on a Manichean perspective, where the people are considered as pure and good, whereas the elites are evil and corrupted (Akkerman, Mudde, and Zaslove 2014; Geurkink et al. 2020; Mudde 2004). Based on the aforementioned definition, it is possible that citizens with a higher degree of populist attitudes consider referendums a more legitimate way of making decisions, preferring referendums out of normative considerations. Indeed, part of the populist ideology is the belief that citizens should be their own rulers and political elites only stand in the way of 'government by the people'. Especially in a consensus democracy, the referendum can add an element of a more majoritarian type of democracy, which better fits the populist set of ideas. Populist citizens may thus hold different values regarding the structure and legitimacy of democratic decision-making (Mohrenberg, Huber, and Freyburg 2019).

While there is a large literature on citizens' process preferences (for example, Bengtsson and Mattila, 2009; Webb, 2013), there are only few empirical studies that assess the relationship between populist attitudes and support for referendums. Those studies that tested the relationship directly found a positive relationship between populist attitudes and support for referendums (Bjånesøy and Ivarsflaten 2016; Jacobs, Akkerman, and Zaslove 2018; Mohrenberg, Huber, and Freyburg 2019).

Based on these previous findings, we formulate a first hypothesis:

Hypothesis 1: The higher the degree of populist attitudes of a citizen, the more they support the referendum in question prior to the vote.

Yet, even if we find such a positive relationship between populist attitudes and referendum support, this need not necessarily mean that support for referendums is based on normative considerations about how democratic decisions ought to be made. In fact, a second, explanation could be that populist citizens favour referendums based on instrumental considerations. Recent studies on process preferences have found that such instrumental considerations generally play an important role in shaping citizens' support for referendums (Landwehr and Harms 2019; Werner 2019), as well as more general attitudes towards electoral reform (Biggers 2019; Bowler, Donovan, and Karp 2006).

While there may be a good theoretical 'fit' between populism and referendums, an alternative expectation is that the subgroup of populist citizens relies on instrumental considerations to support and evaluate referendums, even more so than non-populist citizens. Non-populist citizens may believe that there are other routes to achieve desired policies (for example, expert government or simply via contacting politicians or other types of traditional political participation). 
For them, referendums are just one tool. For populists, referendums are likely to be seen as the single most effective tool, as they bypass the elites by handing over power to the people (see Mohrenberg, Huber, and Freyburg 2019: 4). ${ }^{3}$ Perceived legitimacy is, then, derived not from the process as such, but from the favourability of the outcome. Hence, we expect the relationship between instrumental considerations and support for a referendum to be even stronger among populist citizens.

General studies on process preferences have found that instrumental considerations typically come in two forms (Werner 2019). First, citizens may support a referendum on a given question more so when they are in favour of the policy proposal under discussion. This is because citizens have nothing to lose and much to gain from a referendum on a proposal (or veto of an existing bill) that they endorse. Second, citizens may be more supportive of a referendum if they expect to win the referendum (see also Landwehr and Harms 2019). In both cases, citizens support a referendum because they believe it benefits them. Based on the aforementioned reasoning highlighting that populists consider referendums the single most effective tool to achieve desired policy outcomes, we thus formulate the following two moderator hypotheses:

Hypothesis 2a: The higher the degree of populist attitudes, the stronger the relationship between support for the specific policy proposal and support for a referendum on that topic.

Hypothesis 2b: The higher the degree of populist attitudes, the stronger the relationship between majority perceptions about an issue and support for a referendum on that topic.

If citizens with populist attitudes are not genuinely in favour of referendums, but rather consider them a convenient tool to reach desired policies, this also has consequences for how legitimate they judge the outcome of a referendum. Therefore, the reaction of citizens with populist attitudes that lose referendums is of particular importance to this analysis. Extensive work both on elections and on procedural fairness has shown that outcome favourability plays an important role in shaping citizens' evaluations of the decision-making process and their likelihood to accept the decision (Anderson et al. 2005; Arnesen 2017; Esaiasson et al. 2019; Marien and Kern 2018; Merkley et al. 2019). If populist citizens root their support for referendums in the expectation of favourable outcomes, losing a referendum could lower their willingness to accept the decision (that is, they are 'sore losers') ${ }^{4}$ :

Hypothesis 3: The higher the degree of populist attitudes, the lower the willingness to accept the outcomes of referendums among decision losers. ${ }^{5}$

\section{Methodology}

\section{Case}

We test these hypotheses on a real referendum, namely, the 2018 Dutch referendum on the Intelligence and Security Services Act 2017. Studying a real referendum has the obvious advantage of improving ecological validity compared to hypothetical surveys or experiments. The downside of

\footnotetext{
${ }^{3}$ This reasoning reflects the impact of the anti-elitism component of populism in combination with the populist desire for popular sovereignty. The last component of populism - people-centrism - is unlikely to influence the relationship; here, one would simply expect that populists are more likely to hold majority perceptions, not that the effect of majority perceptions is stronger.

${ }^{4}$ This would be in line with how populist politicians react to losses. When populists in power lose referendums, they tend to react by ignoring the outcome and/or blaming the elites for their loss (Pállinger 2018; Silva 2020; Verdugo 2017). In short, they find it hard 'to take "no" for an answer' (Verdugo 2017).

${ }^{5}$ In the context of this project, we also formulated and tested a hypothesis on changes in referendum support. More information on the argument, hypothesis and results can be found in Table A10 in the Appendix.
} 
our design is that we can only test correlational relationships. Thus, we cannot make causal claims. Further, we have to be cautious in generalizing from this case. To this end, we provide more detailed information on the case in the Online Appendix. What makes this referendum ideally suited to studying the relationships in question is that the policy preference does not overlap substantially with populist attitudes, which can make it difficult to disentangle the role of populist attitudes and loss in the referendum. As Fig. A1 in the Online Appendix shows, we have sufficient variation of populist attitudes among both proponents and opponents of the referendum proposal.

\section{Dataset}

The data were collected by the Longitudinal Internet studies for the Social Sciences (also known as the LISS-panel), a high-quality probability sample survey panel run by CenterData (University of Tilburg). We use data from two waves of the referendum study. Data for the pre-wave were collected in the weeks prior to the referendum (5-20 March; response $=74.2$ per cent). Data for the post-wave were collected after the referendum (22 March-8 April; response $=78.7$ per cent). The sample of the post-wave consists partly of respondents who were also invited to the previous waves and partly of 'fresh' respondents. For the main analyses, we construct an analytical sample including respondents who answered the questionnaire both pre- and post-wave. This yields an analytical sample of 666 respondents. We also conduct a robustness check on our post-wave analysis including the full sample (see Table A6 in the Online Appendix; $N=1,322$ ). The turnout was overestimated in the dataset - a classic problem for survey research about voter turnout. The vote choice distribution is slightly skewed towards decision losers in our analytical sample, yet not in the full post-sample, with which we find substantially the same results (see Table A6 in the Online Appendix). In terms of demographics, our sample compares well to Dutch census data, yet is slightly skewed towards men, older people and higher-educated citizens (Statistics Netherlands 2018). Descriptive information about the sample can be found in Tables A1 and $\mathrm{A} 2$ in the Online Appendix.

\section{Operationalization}

We use two dependent variables. First, we measure support for the referendum on the information law (seven-point scale, measured in the pre-wave and used for H1, H2a and H2b). Second, we measure to what extent citizens were willing to accept the result of the referendum (sevenpoint scale, measured in the post-wave and used for $\mathrm{H} 3$ ).

Our main independent variable is populist attitudes. We use the widely used, standard, sixitem battery of populist attitudes devised by Akkerman, Mudde and Zaslove (2014), measured in the post-wave. It should be noted that one of the items in the scale asks whether citizens should decide instead of politicians on the most important issues. There may be conceptual similarity between this item and support for the specific referendum under study, which is one of our dependent variables. Hence, to err on the side of caution, we decided to drop this item from our main analysis. Robustness checks using the full scale reveal substantially the same results (see Tables A7 and A8 in the Online Appendix).

Further, we measure citizens' policy preferences regarding the information law under question (binary, pre-wave) and their expectation of the referendum result, which is then matched to their policy preference to construct a majority perceptions variable (binary, pre-wave). More information on question wording can be found in the Online Appendix.

\section{Results}

In the following, we test the outlined hypotheses. It should be noted that we control for party preferences in all models, yet do not show them in the main graphs for ease of readability. The complete regression tables can be found in the Online Appendix (see Tables A4 and A5). 


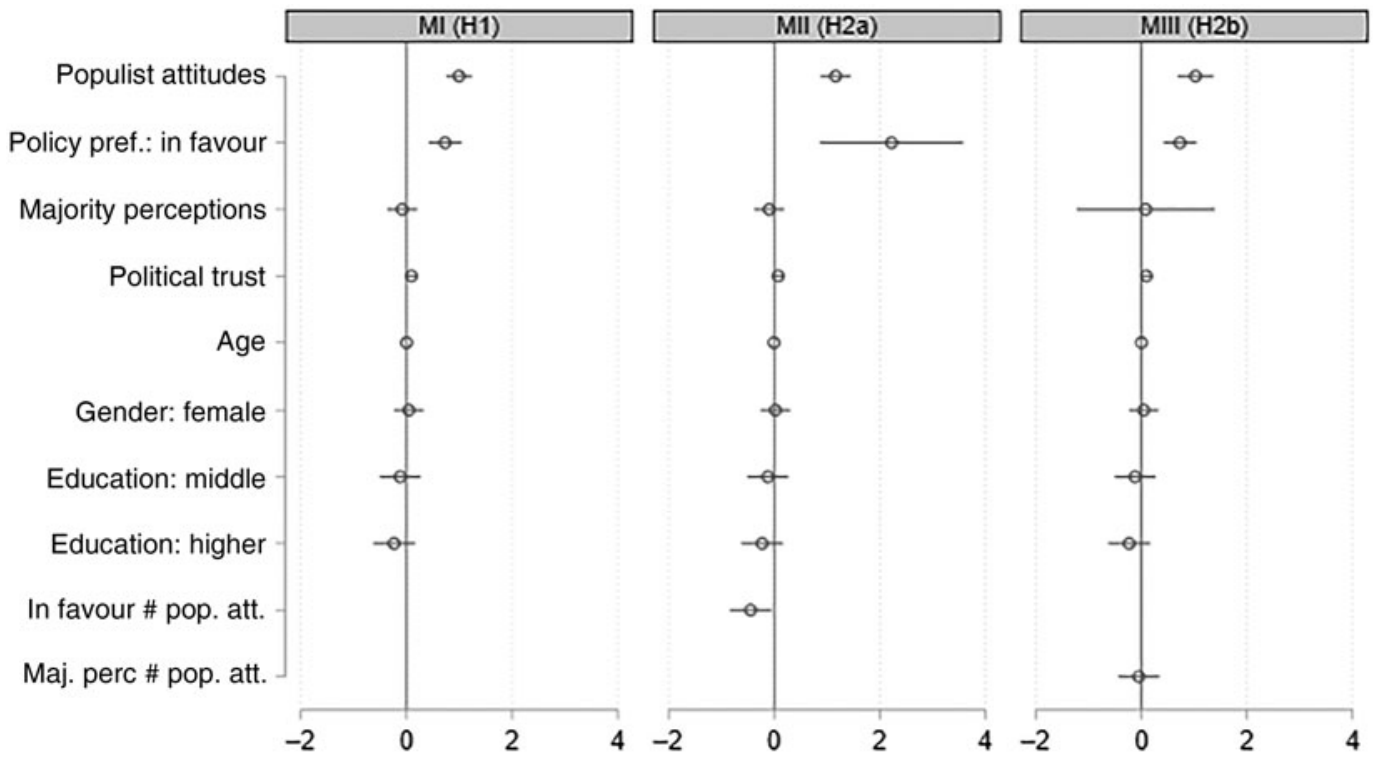

Figure 1. Regression of support for referendum (pre-wave).

Note: Estimates are unstandardized regression coefficients. $\mathrm{N}=666 . \mathrm{R}_{\mathrm{MI}}^{2}=0.23 ; \mathrm{R}^{2}{ }_{\mathrm{MII}}=0.23 ; \mathrm{R}^{2}{ }_{\mathrm{MIII}}=0.23$. Party preference was included in model but is removed for ease of readability. Bars represent 95 per cent confidence intervals. For the corresponding table, see Table A4 in the Online Appendix. Policy pref = Policy preference; Pop. att. = Populist attitudes; Maj. Perc. $=$ Majority perception

H1 predicted that citizens with high levels of populist attitudes would be more supportive of the referendum on the information law than citizens with low levels of populist attitudes. As can be seen in Fig. 1 (Model I), this is indeed the case. Populist attitudes are positively and significantly related to support for the referendum on the information law.

But are populists more instrumental in their support for the referendum? H2a expected that populist attitudes would interact with support for the policy proposal and with the expectation of winning the referendum, indicating that these instrumental considerations are especially prevalent among citizens with populist attitudes. We start with an investigation of the interaction with support for the policy proposal (H2a). As can be seen in Model II, there is indeed a significant interaction between populist attitudes and support for the policy proposal $(p<0.05)$ but in the other direction than predicted. It turns out that populist citizens' support for the referendum is less driven by instrumental concerns about changing a specific policy. This interaction is visualized in Fig. 2.

Turning to the interaction with the expectation of winning $(\mathrm{H} 2 \mathrm{~b})$, we expected that populist citizens would be especially supportive of a referendum if they expect to win it. As Model III shows, this is not the case: we see no indications of an interaction between populist attitudes and majority perceptions (also visualized in Fig. 2).

Our hypotheses about populist attitudes and support for referendums have only partly been confirmed. Replicating results from existing research, we find that citizens with populist attitudes are more in favour of the referendum in question (H1). Furthermore, and contrary to our own expectations, we find that, compared to non-populist citizens, their support is either less driven by instrumental, policy-specific concerns $(\mathrm{H} 2 \mathrm{a})$ or at least not more so in regards to their expectation of winning (H2b).

We now turn to the post-wave to investigate how populist citizens reacted to the outcomes of the referendum. In $\mathrm{H} 3$, we expected that such citizens would be less likely to consider the referendum outcome legitimate if they did not get the desired policy outcome. 

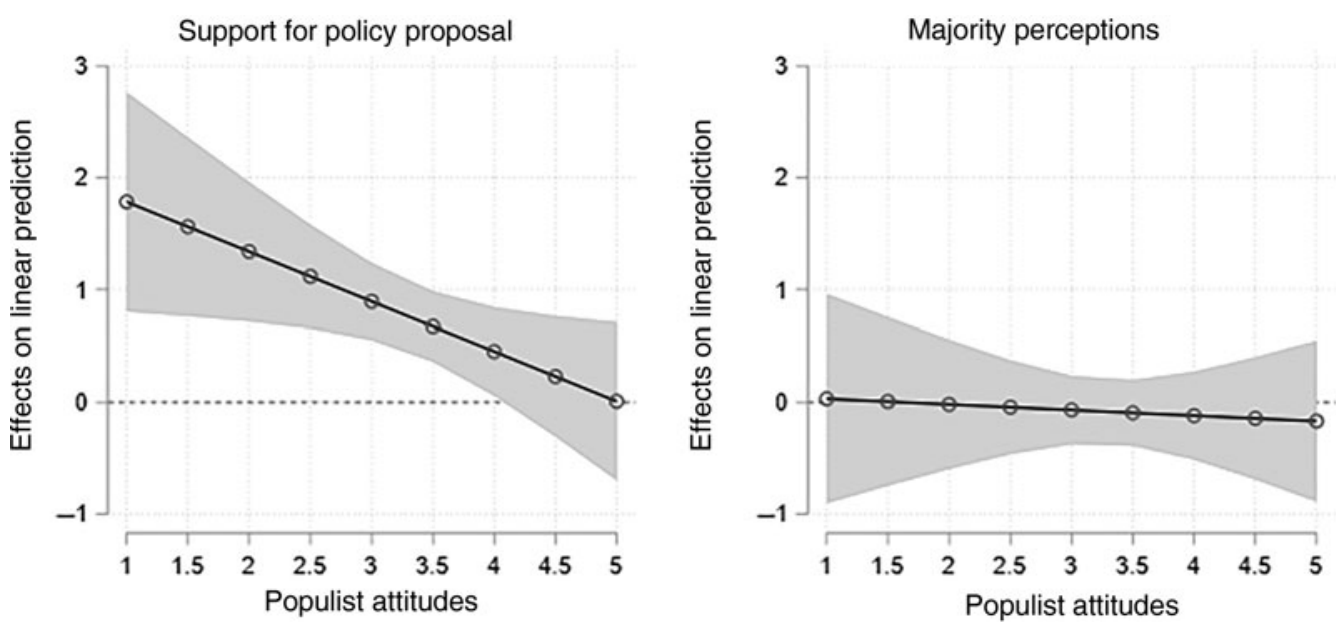

Figure 2. Marginal effects of support for the policy proposal and of majority perceptions on support for the referendum across populist attitudes.

Note: $\mathrm{N}=666$. The graph presents the visualization of the interaction in Model II and Model III of Fig. 1. For the corresponding table, see Table A4 in the Online Appendix.

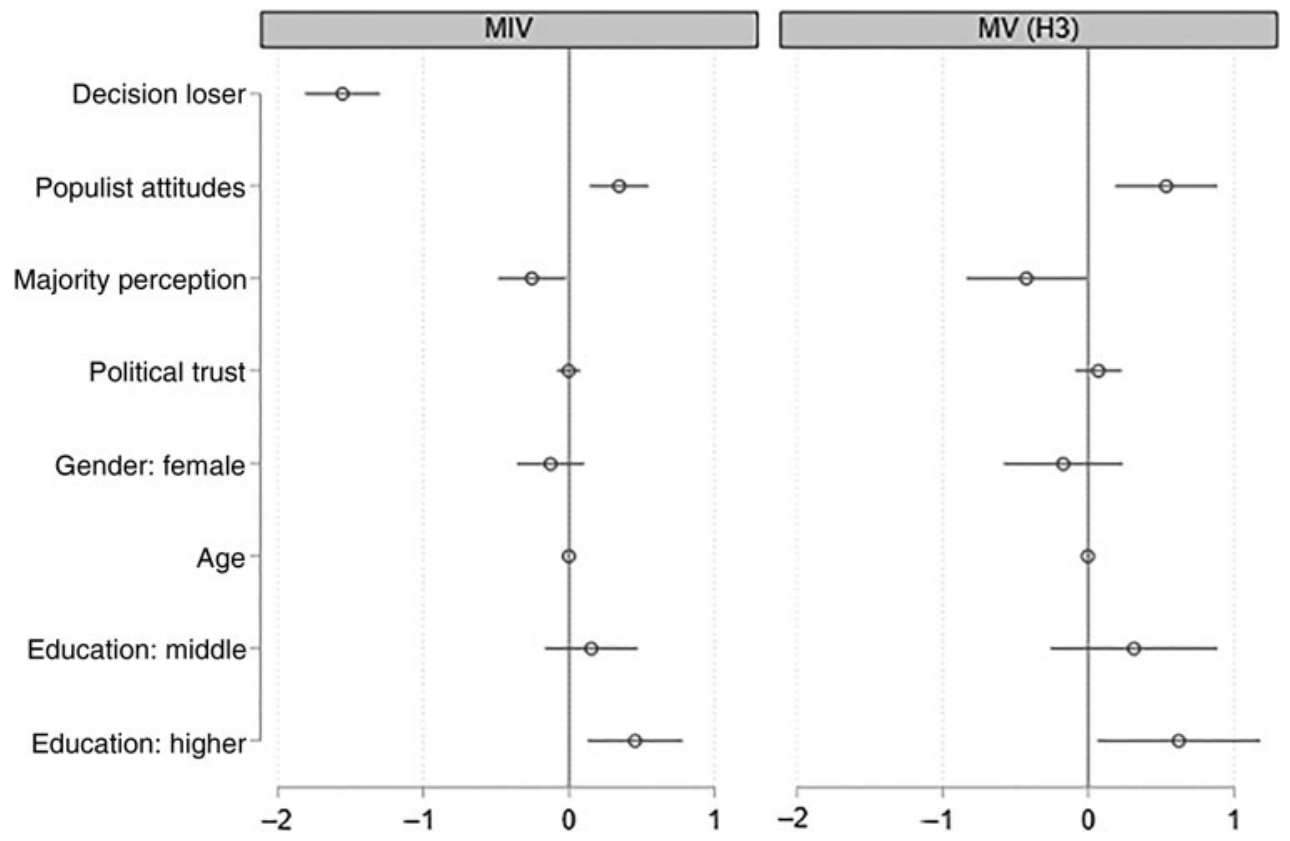

Figure 3. Linear regression of acceptance of the referendum outcome (post-wave).

Note: Estimates are unstandardized regression coefficients. MV shows effects for the subgroup of decision losers. $N_{\text {MIV }}=666, R_{M I V}^{2}=0.29$; $\mathrm{N}_{\mathrm{MV}}=339, \mathrm{R}_{\mathrm{MV}}^{2}=0.10$. Party preference was included in the model but is removed for ease of readability. Bars represent 95 per cent confidence intervals. For the corresponding table, see Table A5 in the Online Appendix.

We first test how acceptance of the referendum result relates to outcome favourability and populist attitudes among the whole sample (see Model IV in Fig. 3). As expected, we see that those who lost exert lower willingness to accept the outcome of the referendum than those who won. Interestingly, populist attitudes are positively (and significantly) associated with 
acceptance of the outcome. However, this could be driven by decision winners (Marien and Kern 2018).

We then turn to the subsample of decision losers in Model V. We expected a negative correlation between populist attitudes and acceptance of the unfavourable referendum result. However, we find the exact opposite: the higher a citizen's degree of populist attitudes, the higher their willingness to accept the unfavourable outcome. It therefore seems that citizens with high populist attitudes are more gracious losers in a referendum than citizens with low populist attitudes, disconfirming our hypothesis.

\section{Robustness Checks}

To check the stability of our findings, we ran several robustness checks. First, we run the analyses on decision acceptance using the full sample of third-wave respondents $(\mathrm{N}=1,322)$ instead of the overlap sample between the pre- and post-wave that we present in the main analysis. We find substantially the same results (see Table A6 in the Online Appendix).

Second, we rerun all our analyses using the full populist attitudes scale. This scale includes the item 'On the most important issues, citizens should decide instead of politicians' that we removed for our main analysis because it related too closely to support for populist attitudes. We find substantially the same results as in our main analysis, with slightly bigger effect sizes. The results can be found in Tables A7 and A8 in the Online Appendix.

Third, we assess the conditionality of our findings on the policy issue of the referendum to gain insights into its generalizability. While there was substantial attention to the topic of data protection in the public debate, it is not the most salient and pressing policy issue for most citizens. We interact the importance that respondents attributed to the policy issues with populist attitudes in our analysis of decision acceptance for both the full sample and the decision losers. We find no significant interaction effect; hence, even populist citizens that cared strongly about the issue were more willing to accept an unfavourable outcome than their non-populist, caring counterparts. The results can be found in Table A9 in the Online Appendix.

\section{Conclusion}

We expected populist citizens to be sore losers when compared to non-populist ones. It turns out that this is not the case in our study. Citizens with populist attitudes were less instrumental and more principled in their support for referendums, and in line with this, they were more accepting of the referendum result, even when the outcome was unfavourable. The obtained results are robust across different analysis specifications.

These findings have a range of implications. First, they shed light on the potential of referendums to strengthen popular legitimacy. The concern about growing dissatisfaction with the political system and resulting low levels of legitimacy is prevalent both in political science and among practitioners. Many critics worry that participatory processes will only appeal to those citizens who are already politically privileged - the interested, trusting and educated citizens - and will cause even more frustration among those who feel excluded and neglected (Smith 2009). Our results suggest that referendums hold a normative appeal to citizens with populist attitudes and could build consent even in the light of unfavourable policy outcomes. It seems that populist citizens are not necessarily up for ignoring the rules of the game; they just think there should be different rules.

However, a second implication opens up a problem for political practice. What should be done if different subgroups of the population consider different decision-making arrangements as legitimate? For instance, it could be that citizens are dissatisfied but, at the same time, consider their fellow citizens incompetent. Such citizens are likely to prefer expert democracy and dislike referendums. This causes a conflict between the normative democratic preferences of different societal groups, one that is not easily resolved and requires the consideration of other democratic goods. 
As with every study, ours comes with some limitations. First of all, we could only study correlations between our variables of interest and can therefore only theorize about the causal relationships. Second, since we use data from a single referendum, questions of generalizability may arise. While the Dutch 2018 referendum is an excellent first testing ground to examine the relationship between populist attitudes and losing referendums, as populist citizens were relatively evenly distributed in terms of winning and losing, it is important to test the findings in other country settings as well. Although our study indicates that populist citizens' support for referendums is more normative and, consequently, can correlate positively with decision acceptance, it remains to be examined under which circumstances such correlations materialize. Third, it remains to be seen whether populist citizens would behave similarly for highly contested issues, such as migration. While our data suggest that issue importance does not change populist citizens' willingness to accept the decision, future studies are required. Evidently, while a crucial one, our research constitutes only a first step. Indeed, it remains to be investigated further under which specific circumstances and to what extent referendums can help bring populist citizens back in.

Supplementary Material. Online appendices are available at: https://doi.org/10.1017/S0007123421000314.

Data Availability Statement. The dataset used for the analyses in this manuscript is publicly available and can be found at: https://www.dataarchive.lissdata.nl/study_units/view/815. Replication code (see Werner and Jacobs 2021) can be found at the Harvard Dataverse: https://doi.org/10.7910/DVN/DTN3JF.

Acknowledgements. We thank Wouter van der Brug, André Bächtiger and Saskia Ruth-Lovell, as well as the three anonymous reviewers, for helpful comments on this article.

Funding. Part of this research was financed via Dutch National Science Fund (NWO) as part of the NWO-VIDI project no. 195.085. This project has also received funding from the European Research Council under the European Union's Horizon 2020 research and innovation programme (grant agreement No. 759736).

\section{References}

Akkerman A, Mudde C and Zaslove A (2014) How populist are the people? Measuring populist attitudes in voters. Comparative Political Studies 47(9), 1324-1353.

Anderson C et al. (2005) Losers' Consent: Elections and Democratic Legitimacy. Oxford: Oxford University Press.

Arnesen S (2017) Legitimacy from decision-making influence and outcome favourability: results from general population survey experiments. Political Studies 65(15), 146-161.

Bengtsson A and Mattila M (2009) Direct democracy and its critics: Support for direct democracy and 'stealth' democracy in Finland. West European Politics 32(5), 1031-1048.

Biggers D (2019) Does partisan self-interest dictate support for election reform? Experimental evidence on the willingness of citizens to alter the costs of voting for electoral gain. Political Behavior 41(4), 1025-1046.

Bjånesøy L and Ivarsflaten E (2016) What kind of challenge? Right-wing populism in contemporary Western Europe. In Peters Y and Tatham M (eds) Democratic Transformations in Europe. Challenges and Opportunities. London: Routledge, pp. 33-50.

Bowler S and Donovan T (2013) The Limits of Electoral Reform. Oxford: Oxford University Press.

Bowler S, Donovan T and Karp J (2006) Why politicians like electoral institutions: self-interest, values, or ideology? The Journal of Politics 68(2), 434-446.

Bowler S, Donovan T and Karp J (2007) Enraged or engaged? Preferences for direct citizen participation in affluent democracies. Political Research Quarterly 60(3), 351-362.

Esaiasson P et al. (2019) Reconsidering the role of procedures for decision acceptance. British Journal of Political Science 49, 291-314.

Geurkink B et al. (2020) Populist attitudes, political trust, and external political efficacy: old wine in new bottles? Political Studies 68(1), 247-267.

Jacobs K, Akkerman A and Zaslove A (2018) The voice of populist people? Referendum preferences, practices and populist attitudes. Acta Politica 53(4), 517-541.

Landwehr C and Harms P (2019) Preferences for referenda: intrinsic or instrumental? Evidence from a survey experiment. Political Studies 68(4), 875-894.

Marien S and Kern A (2018) The winner takes it all: revisiting the effect of direct democracy on citizens' political support. Political Behavior 40(4), 857-882. 
Merkley E et al. (2019) Having their say: authority, voice, and satisfaction with democracy. The Journal of Politics 81(3), 848-861.

Mohrenberg S, Huber R and Freyburg T (2019) Love at first sight? Populist attitudes and support for direct democracy. Party Politics 27(3), 528-539.

Mudde C (2004) The populist zeitgeist. Government and Opposition 39(4), 541-563.

Pállinger Z (2018) Direct democracy in an increasingly illiberal setting: the case of the Hungarian national referendum. Contemporary Politics 25(1), 62-77.

Rooduijn M (2019) State of the field: how to study populism and adjacent topics? A plea for both more and less focus. European Journal of Political Research 58(1), 362-372.

Scarrow S (2001) Direct democracy and institutional change: a comparative investigation. Comparative Political Studies 34(6), $651-665$.

Silva B (2020) 'He's not one of them!' Antiestablishment supporters of populist governments in Bolivia and Ecuador. The Journal of Politics 81(3), 1085-1089.

Smith G (2009) Democratic Innovations: Designing Institutions for Citizen Participation. Cambridge: Cambridge University Press.

Statistics Netherlands (2018) Statline. The Netherlands in figures. Avaiable from https://opendata.cbs.nl/statline/\#/CBS/en/ (accessed December 2020).

Verdugo S (2017) How the Bolivian Constitutional Court helped the Morales regime to break the political insurance of the Bolivian Constitution. International Journal of Constitutional Law Blog. Available from http://www.iconnectblog.com/ 2017/12/how-the-bolivian-constitutional-court-helped-the-morales-regime-to-break-the-political-insurance-of-the-bolivianconstitution/ (accessed 22 August 2019).

Webb P (2013) Who is willing to participate? Dissatisfied democrats, stealth democrats and populists in the United Kingdom. European Journal of Political Research 52(6), 747-772.

Werner H (2019) If I'll win it, I want it. The role of instrumental considerations in explaining public support for decisionmaking through referendums. European Journal of Political Research 59(2), 312-330.

Werner H and Jacobs K (2021) "Replication Data for 'Are populists sore losers? Explaining populist citizens' preferences for and reactions to referendums”, https://doi.org/10.7910/DVN/DTN3JF. Harvard Dataverse, V1, UNF:6:eS0iDokZGlQWM PpM3MSOAA $==[$ fileUNF $]$.

Cite this article: Werner H, Jacobs K (2022). Are Populists Sore Losers? Explaining Populist Citizens' Preferences for and Reactions to Referendums. British Journal of Political Science 52, 1409-1417. https://doi.org/10.1017/S0007123421000314 